\title{
ANALISIS EFEKTIFITAS PENGGUNAAN CADANGAN DEVISA, UTANG LUAR NEGERI DAN EKSPOR TERHADAP STABILITAS NILAI TUKAR
}

\author{
Mohammad Yusuf ${ }^{1}$ \\ Reza Nurul Ichsan ${ }^{2}$ \\ Universitas Pembangunan Panca Budi ${ }^{1}$ \\ Universitas Pembinaan Masyarakat Indonesia Medan ${ }^{2}$ \\ Email : yusuflangit8@gmail.com \\ Email : rezaichsan31@gmail.com
}

\begin{abstract}
Abstrak
Adapun penelitian ini bermakna untuk mendalami penelitian mandiri yang berjudul Analisis Efektifitas Penggunaan Cadangan Devisa, Utang Luar Negeri dan Ekspor Terhadap Stabilitas Nilai Tukar. Selanjutnya sebagai variabel independen dalam penelitian mandiri ini adalah Cadangan Devisa, Utang Luar Negeri dan Ekspor. Sementara itu variabel dependen adalah Stabilitas Nilai Tukar. Sistem penelitian ini memakai suatu metode analisis data yang dimanfaatkan adalah penelitian asosiatif/kuantitatif yang dianalisis dengan menggunakan alat yang bernama Uji Statistik Deskriftif dalam uji ini memanfaatkan sebuah program yang bernama program E-Views. Selain menggunakan alat uji statistik deskriftif juga memanfaatkan uji Asumsi Klasik. Adapun uji asumsi klasik yang digunakan mencakup uji normalitas, uji multikolinearitas, uji linearitas dan uji autokorelasi. Adapun mengenai pengujian test goodness of fit memanfaatkan sebuah formula interpretasi yaitu interpretasi Nilai $R$ (Koefisien Determinasi), Interpretasi Uji $F$ (Fisher) dan interpretasi Uji t. Selanjutnya data yang dimanfaatkan dalam penelitian mandiri ini adalah data sekunder yang bersumber dari Bank Indonesia dan Biro Pusata Statistik yang dianalisis dengan memanfaatkan metode kuantitatif dengan pendekatan diskriftif dan populasi penelitian adalah laporan Analisis Efektifitas Penggunaan Cadangan Devisa, Utang Luar Negeri dan Ekspor Terhadap Stabilitas Nilai Tukar. Dari hasil penelitian mandiri ini menkonklusikan bahwa Analisis Efektifitas Penggunaan Cadangan Devisa, Utang Luar Negeri dan Ekspor Terhadap Stabilitas Nilai Tukar memiliki pengaruh positif dan signifikan terhadap Terhadap Stabilitas Nilai Tukar.
\end{abstract}

Kata kunci: stabilitas nilai tukar, cadangan devisa, utang luar negeri, ekspor.

\begin{abstract}
The research is meaningful to explore an independent study entitled Analysis of the Effectiveness of the Use of Foreign Exchange Reserves, Foreign Debt and Exports to Exchange Rate Stability. Furthermore, as an independent variable in this independent study are foreign exchange reserves, foreign debt and exports. Meanwhile the dependent variable is Exchange Rate Stability. This esearch system uses a data analysis method that is utilized is associative / quantitative research that is analyzed using the Descriptive Statistics Test in this test utilizing a program called the E-Views program. In addition to using descriptive statistical test tools also utilize the Classical Assumptions test. The classic assumption tests used include normality test, multicollinearity test, linearity test and autocorrelation test. As for testing the goodness of fit test utilizing an interpretation formula that is the interpretation of the $R$ Value (Coefficient of Determination), Interpretation of the F Test (Fisher) and the interpretation of the t test. Furthermore, the data utilized in this independent study are secondary data sourced from Bank Indonesia and the Bureau of Statistics, which are analyzed using quantitative methods with a discrete approach and the study population is the report on the Effectiveness Analysis of the Use of Foreign Exchange Reserves, Foreign Debt and Exports Against Exchange Rate Stability. From the results of this independent study concludes that Analysis of the Effectiveness of the Use of Foreign Exchange Reserves, Foreign Debt and Exports on Exchange Rate Stability has a positive and significant effect on Exchange Rate Stability.
\end{abstract}


Keywords: exchange rate stability, foreign exchange reserves, foreign debt, exports.

\section{PENDAHULUAN.}

Nilai tukar atau kurs merupakan indikator ekonomi yang sangat penting karena pergerakan nilai tukar berpengaruh luas terhadap aspek perekonomian suatu negara. Saat ini perkembangan sistem perekonomian ke arah yang lebih terbuka antar negara. Nilai tukar memainkan peran vital dalam tingkat perdagangan sebuah negara, dimana merupakan sesuatu yang paling kritis bagi mayoritas ekonomi pasar bebas di dunia. Sementara itu setiap negara menginginkan nilai tukar yang stabil. Suatu negara dikatakan surplus dalam neraca perdagangan apabila nilai ekspor lebih tinggi dari impor. Sedangkan neraca perdagangan dikatakan defisit apabila nilai impor lebih besar daripada ekspor. Ketika nilai tukar rupiah mengalami depresiasi, maka pemerintah melakukan intervensi dengan menggunakan cadangan devisa di pasar valas. Pemerintah akan menjual valas untuk ditukarkan kembali dengan rupiah untuk menstabilkan kurs.

Selanjutnya adapuncadangan devisa di Indonesia dalam kurun waktu 8 tahun yakni pada tahun 2009-2016 mengalami fluktuasi. Awal tahun 2009 cadangan devisa sebesar 50,870.00 juta USD dan terus meningkat hingga Agustus 2011 mencapai $124,637.75$ juta USD. Namun pada bulan berikutnya, cadangan devisa menurun oleh karena tekanan pada transaksi modal dan finansial yang mengalami defisit sebesar Rp 3,4 miliar.

Selanjutnya mengenai utang luar negeri Indonesia. Utang luar negeri menjadi salah satu unsur yang tidak terpisahkan dari proses pembiayaan pembangunan bagi negara-negara berkembang, khususnya Indonesia. Pada umumnya, sumber dana dalam negeri yang diperoleh dari berbagai jenis pajak, devisa hasil ekspor, dan dana internal lainnya masih terbatas jumlahnya. Tentunya hal ini belum mencukupi kebutuhan pembangunan yang sedemikian besarnya sehingga harus ditutup dengan utang luar negeri. Sementara itu kebijakan utang luar negeri diatur dalam Undang-undang Nomor 17 Tahun 2003 tentang Keuangan Negara, yaitu pada Pasal 23 ayat (1) yang berbunyi "Pemerintah pusat dapat menerima dan memberikan hibah atau pinjaman dari pemerintah atau lembaga asing dengan persetujuan Dewan Perwakilan Rakyat (DPR)." dan pasal 12 ayat (3) yaitu "Defisit anggaran dimaksud dibatasi maksimal 3\% dari Produk Domestik Bruto (PDB). Jumlah pinjaman dibatasi maksimal $60 \%$ dari PDB."

Ekspor adalah suatu proses dimana barang atau komoditas dari suatunegara dikirimkan ke negara lain. Perusahaan dengan skala bisnis kecilsampai dengan menengah biasanya menggunakan proses tersebut sebagai strategi utama untuk bersaing di tingkat internasional.Kegiatan ekspor adalahsistem perdagangan dengan cara mengeluarkan barang-barang dari dalamnegeri keluar negeri dengan memenuhi ketentuan yang berlaku. Ekspor merupakan total barang dan jasa yang dijual oleh sebuah negara ke negaralain, termasuk diantara barang-barang, asuransi, dan jasa-jasa pada suatu tahun tertentu (Triyoso, 2004).

\section{METODE}

\subsection{Materi Penelitian}

Penelitian asosiatif merupakan penelitian yang bertujuan untuk mengetahui pengaruh ataupun juga hubungan antara dua variabel atau lebih. Penelitian ini mempunyai tingkatan tertinggi dibandingkan dengan diskriptif dan komparatif karena dengan penelitian ini dapat dibangun suatu teori yang dapat berfungsi unguk menjelaskan, meramalkan dan mengontrol suatu gejala. Penelitian ini 
melalui pendekatan penelitian asosiatif/ kuantitatif. Menurut Sugiyono (2010) Penelitian asosiatif adalah merupakan penelitian yang bertujuan untuk mengetahui antara dua variabel atau lebih.

\subsection{Prosedur Penelitian}

Adapun prosedur penelitian merupakan langkah-langkah penelitian dari awal hingga akhir. Prosedur penelitian diuraikan menjadi tiga, yaitu tahap pengumpulan data, tahap analisis, dan tahap simpulan.yakni :Tahan Pengumpulan, Tahap pertama dalam penelitian ini adalah tahap pengumpulan data. Tahap ini untuk melakukan pengumpulan data yang terdapat pada Cadangan Devisa, Utang Luar Negeri, Ekspor dan stabilitas nilai tukar di Indonesia yang sudah terkumpul dan dianalisis. Setelah itu tahap Analisis yakni tahap kedua dalam penelitian ini adalah tahap analisis. Setelah data berupa hasil pada Cadangan Devisa, Utang Luar Negeri, Ekspor dan stabilitas nilai tukar di Indonesia yang sudah terkumpul dianalisis dengan menggunakan teori, setelah itu dianalisis dengan tujuan penelitian yang akan dilakukan. Terakhir tahap kesimpulan, yaitu : tahap kesimpulan. Kesimpulan dilakukan setelah analisis dilakukan oleh penelitian, sehingga dapat diketahui hasilnya.

\subsection{Paramater Yang Diamati}

Parameter penelitian adalah suatu hubungan atau kaitan antara konsep satu terhadap konsep yang lainya dari masalah yang ingin diteliti. Parameter konsep ini gunanya untuk menghubungkan atau menjelaskan secara panjang lebar tentang suatu topik yang akan dibahas.

\subsection{Tempat dan Waktu Penelitian}

Tempat Penelitian, Penelitian ini dilakukan di wilayah Propinsi Sumatera Utara, Indonesia. Waktu penelitian, Penelitian ini dilakukan mulai dari Bulan
Februari 2019 sampai dengan Bulan Mei 2019.

\subsection{Jenis dan Ruang Lingkup Penelitian}

Data yang digunakan dalam peneltian ini adalah data kuantitatif time series tahunan mulai Tahun 2014 sampai Tahun 2018. Jenis data dan sumber data yang digunakan dalam penelitian ini adalah ;Nilai tukar yang digunakan adalah data nilai tukar Indonesia. Data nilai tukar diperoleh dengan melakukan penelitian studi pustaka, arsip dan laporan yang dikeluarkan oleh Badan Pusat Statistik Sumatera Utara dan Bank Indonesia. Cadangan Devisa yang digunakan adalah data diperoleh dengan melakukan penelitian studi pustaka, arsip dan laporan yang dikeluarkan oleh Badan Pusat Statistik dan Bank Indonesia. Data utang luar negeri yang digunakan adalah data diperoleh dengan melakukan penelitian studi pustaka, arsip dan laporan yang dikeluarkan oleh Badan Pusat Statistik dan Bank Indonesia. Data ekspor yang digunakan adalah data diperoleh dengan melakukan penelitian studi pustaka, arsip dan laporan yang dikeluarkan oleh Badan Pusat Statistik dan Bank Indonesia.

\subsection{Teknik Pengumpulan Data}

Data yang diperlukan dalam penelitian ini adalah data sekunder yang diperoleh dari publikasi resmi lembaga pemerintah yaitu Badan Pusat Statistik Sumatera Utara, Bank Indonesia (BI), dan pengamatan langsung dari situs resmi Badan Pusat Statistik Sumatera Utara, dan Bank Indonesia (BI). Berdasarkan hal tersebut di atas maka metode pengumpulan data yang digunakan adalah penelitian kepustakaan dan penelitian dokumentasi.

\subsection{Populasi dan Sampel}

Adapun populasi adalah Populasi adalah sekumpulan objek yang menjadi pusat perhatian, yang padanya terkandung informasi yang ingin diketahui. Objek ini disebut dengan satuan analisis. Satuan analisis ini 
memiliki kesamaan perilaku atau karakteristik yang ingin diteliti. Populasi dalam penelitian adalah laporan nilai tukar (KURS), Cadang Devisa (CDV), Utang Luar Negeri (ULN) dan Ekspor (EKS) di Indonesia. Sampel yang digunakan adalah purposive sampling, yaitu teknik penentuan sampel dengan pertimbanga tertentu. Sampel diambil dengan kriteria yaitu tahun 2104 sampai dengan tahun 2018 (merupakan 5 tahun terakhir dari data penelitin).

\subsection{Metode Analisis Data}

Model analisis yang digunakan dalam menganalis data adalah model ekonometrik yaitu model yang menyatakan antara deret waktu (time series) dan data kerat lintang (cross section) menghasilkan data yang disebut dengan oabel data ( pooled data). Sehingga panel data mempunyai deret waktu $\mathrm{T}>1$ dan kerat lintang $\mathrm{N}>1$. Menurut Agus Widarjono (2009) penggunaan data panel dalam sebuah observasi mempunyai beberapa keuntungan yang diperoleh. Pertama, data panel yang merupakan gabungan dua data time series dan cross section mampu menyediakan data yang lebih banyak sehingga akan lebih menghasilkan degree of freedom yang lebih besar. Kedua, menggabungkan informasi dari data time series dan cross section dapat mengatasi masalah yang timbul ketika ada masalah penghilangan variabel (omitted-variabel).

\section{HASIL DAN PEMBAHASAN}

\subsection{Hasil Penelitian}

Nilai Tukar atau kurs (exchange rate) adalah tingkat dimana mata uang domestik dikonversikan menjadi mata uang asing. Kurs (exchange rate) dua negara adalah tingkat harga yang disepakati penduduk kedua negara untuk saling melakukan perdagangan. Berikut ini data Nilai Tukar tahun 2014-2018. Penulis melakukan penelitian ini dengan menggunakan Analisis regresi linier berganda dengan commen intercept, penulis menggunakan software eviews versi 7, dan didapatkan hasil output eviews sebagai berikut :

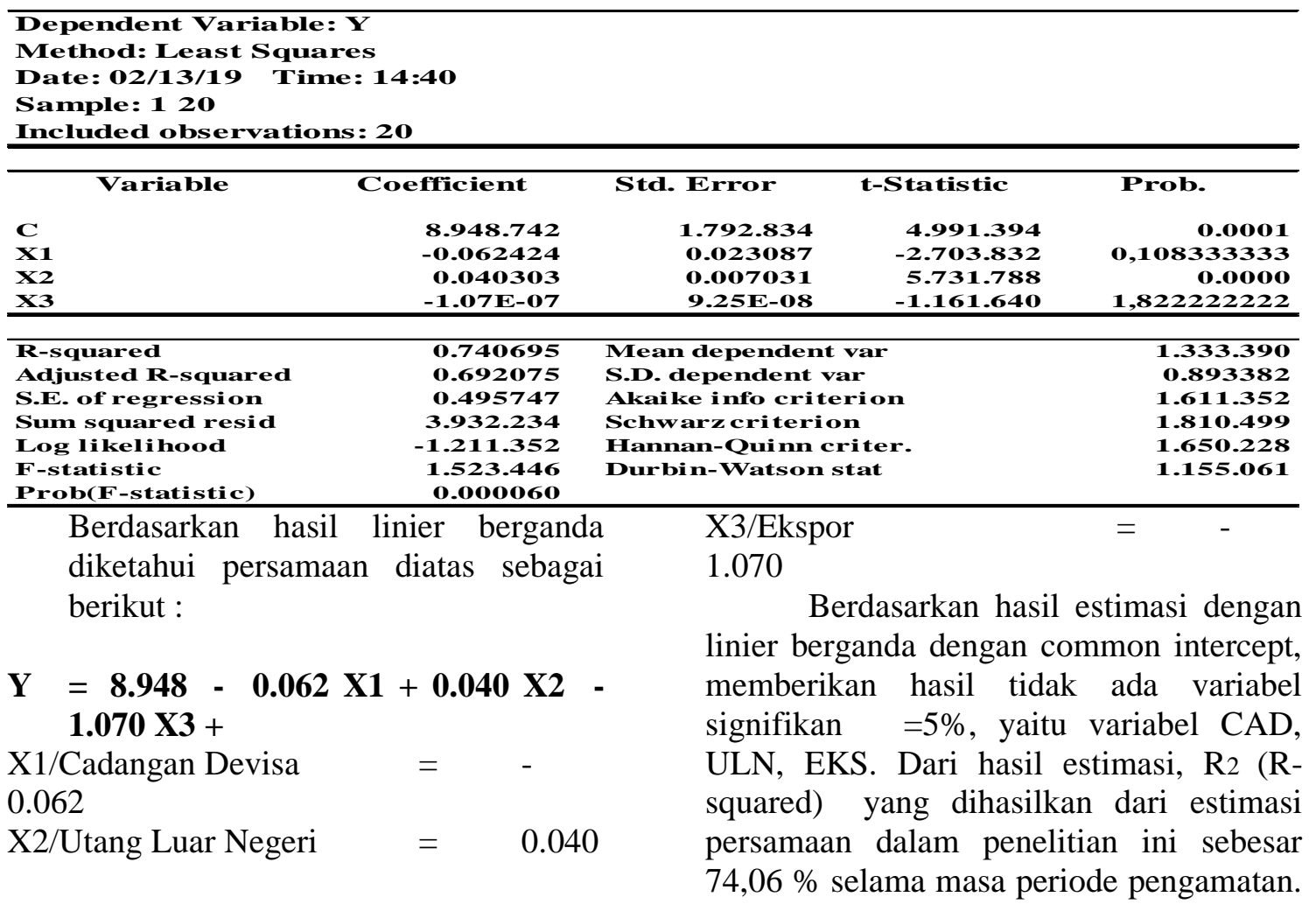


Hal ini dapat disimpulkan bahwa dengan metode analisis linier berganda dengan common intercept, variasi variabel independent dalam penelitian ini hanya mampu menjelaskan $74,06 \%$ variasi variabel dependent yaitu nilai tukar di Indonesia, sementara sisanya sebesar $25,94 \%$ dijelaskan oleh variabel lain yang tidak disertakan dalam model penelitian. Konstanta sebesar 8,948, artinya apabila cadangan devisa, utang luar negeri dan ekspor tidak ada atau nilainya adalah 0, maka keputusan nilai tukar nilainya sebesar 8,948 .

\subsection{Interpretasi Nilai $\mathbf{R}$ Square (Koefisien Determinan)}

Nilai koefisien determinasi adalah antara 0 dan 1. Nilai R2 yang kecil berarti variasi variabel dependen yang sangat terbatas, dan nilai yang mendekati 1 berarti variabel-variabel independen sudah dapat memberi semua informasi yang dibutuhkan untuk memprediksi variabel dependen. Secara umum koefisien determinasi untk data silang relative rendah karena adanya variasi yang besar masing-masing pengamatan, sedangkan data untuk runtut waktu biasanya mempunyai data koefisien determinasi yang lebih tinggi.

\subsection{Interpretasi Uji Asumsi Klasik 1) Uji Normalitas.}

Uji Normalitas adalah sebuah uji yang dilakukan dengan tujuan untuk menilai sebaran data pada sebuah kelompok data atau variabel, apakah sebaran data tersebut berdistribusi normal ataukah tidak. Uji Normalitas berguna untuk menentukan data yang telah dikumpulkan berdistribusi normal atau diambil dari populasi normal. Metode klasik dalam pengujian normalitas suatu data tidak begitu rumit. Berdasarkan pengalaman empiris beberapa pakar statistik, data yang banyaknya lebih dari 30 angka (n > 30), maka sudah dapat diasumsikan berdistribusi normal. Biasa dikatakan sebagai sampel besar.
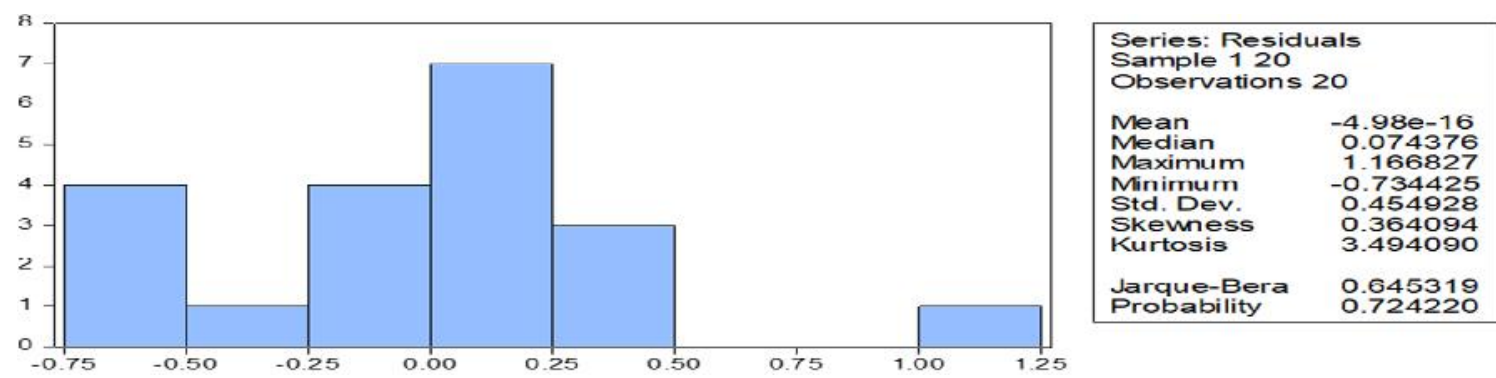

Berdasarkan hasil estimasi uji JB test pada tebel di atsa, diperoleh besarnya nilai Jarque-Bera pada probability sebesar $0.724>0.05$, maka dapat dsimpulkan bahwa data berdistribusi normal. Hal ini berarti model empiris yang digunakan dalam model tersebut mempunyai residual atau faktor pengganggu berdistribusi normal yang tidak ditolak.

2) Uji Linieritas.

Untuk regresi linier berganda, pengujian terhadap linieritas dapat menggunakan Ramsey Reset Test. Jika nilai probabilitas $\mathrm{F}$ hitung lebih besar dari alpha maka model regresi memenuhi asumsi linieritas dan sebaliknya. Nilai probabilitas $\mathrm{F}$ hitung dapat dilihat pada baris $\mathrm{F}$ statistik kolom probability. 


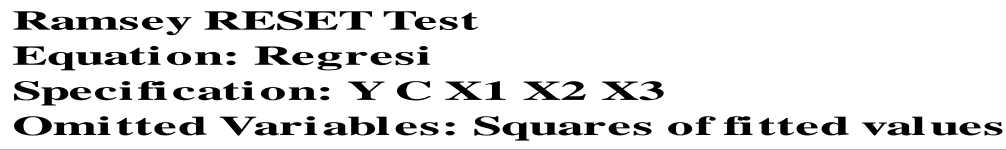

\begin{tabular}{|c|c|c|c|}
\hline & $\begin{array}{l}\text { Value } \\
323768\end{array}$ & df & Probabi li ty \\
\hline $\begin{array}{l}\text { t-statistic } \\
\text { F-statistic }\end{array}$ & $\begin{array}{l}1.323 .768 \\
1.752 .362 \\
2.209 .781\end{array}$ & $(1,15)$ & $\begin{array}{l}0.2054 \\
0.2054 \\
0.1374\end{array}$ \\
\hline
\end{tabular}

\section{3) Uji Autokorelasi}

Adapun autokorelasi merupakan pelanggaran asumsi non-autokorelasi. Hal ini disebabkan karena adanya korelasi antar gangguan/errorpada setiap pengamatan. Autokorelasi juga dapat dikatakan kesalahan dari gangguan periode tertentu berkorelasi dengan gangguan/error dari periode sebelumnya. Permasalahan autokorelasi muncul karena observasi yang berurutan sepanjang waktu atau berkaitan satu sama lain. Masalah ini timbul karena residual (kesalahan penganggu) tidak bebas dari satu observasi ke observasi lainnya. Hal ini sering ditemukan pada data runtun waktu atau time series karena gangguan pada individu/kelompok yang sama pada periode berikutnya. Model regresi yang baik adalah regresi yang bebas autokorelasi.

Breusch-Godfrey Serial Correlation LM Test:

\begin{tabular}{lllr}
\hline F-statistic & 1.663 .022 & Prob. F(2,14) & 1,56181 \\
Obs*R-squared & 3.839 .357 & Prob.Chi-Square(2) & 1,01875
\end{tabular}

Test Equation:

Dependent Variable: RESID

Method: Least Squares

Date: 02/13/19 Time: 14:44

Sample: 120

Included observations: 20

Presamnle missing value lagoed residuals set to zero

Berdasarkan hasil estimasi bahwa

uji LM Test diketahui nilai Obs*R-Squared sebesar 3.839 . selanjutnya F-Statistic sebesaar 1.663, dan Prob. Chi-Square (2) sebesar 1,01875 .

\subsection{Pembahasan}

1. Pengaruh negatif Cadangan Devisa terhadap Nilai Tukar.

Berdasarkan hasil pengujian yang menggunakan Random Effect method dengan Generalized Least Square dengan menggunakan software eviews 7 telah dilakukan, diketahui bahwa variabel Cadangan Devisa berpengaruh negatif dengan nilai koefisien regresi CAD adalah sebesar 0,062 . Namun nilai prob t statistic 0,001 $<0,05$ pada tingkat kepercayaan $95 \%$ $(\alpha=5 \%)$ sehingga dinyatakan bahwa pengaruh CAD signifikan terhadap Nilai Tukar di Indonesia. Kesimpulan hasil ini juga dapat terlihat bahwa pengaruh CAD terhadap Nilai Tukar di Indonesia berpengaruh negatif dan signifikan.

2. Pengaruh positif Utang Luar Negeri terhadap Nilai Tukar.

Berdasarkan hasil pengujian yang menggunakan Random Effect method dengan Generalized Least Square dengan menggunakan software eviews 7 telah dilakukan, diketahui bahwa variabel Utang Luar Negeri berpengaruh positif dengan nilai koefisien regresi ULN adalah sebesar 0.040 Namun nilai prob t statistic 0,108 $>0,05$ pada tingkat kepercayaan $95 \%$ $(\alpha=5 \%)$ sehingga dinyatakan bahwa pengaruh Utang Luar Negeri tidak signifikan terhadap Nilai Tukar di Indonesia. Kesimpulan hasil ini juga dapat terlihat bahwa pengaruh ULN terhadap Nilai Tukar di Indonesia berpengaruh positif namun tidak signifikan. 
3. Pengaruh negatif ekspor terhadap Nilai Tukar.

Berdasarkan hasil pengujian yang menggunakan Random Effect method dengan Generalized Least Square dengan menggunakan software eviews 7 telah dilakukan, diketahui bahwa variabel ekspor berpengaruh negatif dengan nilai koefisien regresi ekspor adalah sebesar -1.070 . Sedangkan nilai prob t statistic $1.822>0,05$ pada tingkat kepercayaan $95 \% \quad(\alpha=5 \%) \quad$ sehingga dinyatakan bahwa pengaruh Ekspor sangat tidak signifikan terhadap nilai tukar di Indonesia. Kesimpulan hasil ini juga dapat terlihat bahwa pengaruh Ekspor terhadap nilai tukar di Indonesia berpengaruh negatif dan tidak signifikan.

\section{KESIMPULAN}

Penelitian ini dilakukan untuk melihat apakah Cadangan Devisa, utang Luar Neeri dan Ekspor dapat mempengaruhi NilaiTukar di Indonesia. Berdasarkan hasil penelitian yang telah dilakukan, maka dapat ditarik kesimpulan sebagai berikut :

1. Cadangan Devisa mempunyai pengaruh negatif dan signifikan terhadap Nilai Tukar di Indonesia.

2. Utang Luar Negeri mempunyai pengaruh positif dan tidak signifikan terhadap Nilai Tukar di Indonesia.

3. Ekspor mempunyai pengaruh negative dan tidak signifikan terhadap Nilai Tukar di Indonesia.

\section{DAFTAR PUSTAKA}

Abimanyu, Yoopi. (2004). memahami kurs valuta asing. Jakarta: Fakultas Ekonomi Unversitas Indinesia.

Achmad Tjahjono. Akuntansi Suatu Pengantar 2, Cetakan 1. (2009). Yogyakarta: Ganbika .

Amir, M.S. (2001). Ekspor Impor Teori \& Penerapannya. PPM. Jakarta.

Amiri, Farhad., Jalal Jasour., Mohsen Shirpour., and Tohid Alizadeh.
(2012). Evaluation of Effective Fashionism Involvement Factors on Impulse Buying of Costumers and Condition of Interrelation between These Factor.Journal of Basic and Applied Scientific Research. 2(9), pp: 9413 9419.

Astanti, Ayu. (2015). "Analisis Kausalitas Antara Utang Luar Negeri dan Pertumbuhan Ekonomi di Indonesia Tahun 1990-2013”. [Skripsi] Ilmu Ekonomi dan Studi Pembangunan. Fakultas Ekonomi Universitas Jember : Jember.

Basri, Faisal, (2003). Perekonomian Indonesia, Jakarta : Erlangga

Blanchard, Olivier. (2000). Macroeconomics. Prentice-Hall, Inc. New Jersey. 548 pages.

Gie, Kwik Kian. (1999). Gonjangganjing Ekonomi Indonesia Badai Belum Akan Segera Berlalu. Gramedia Pustaka Utama

Krugman, Paul R dan Maurice Obstfeld, (1994) Ekonomi Internasional :Teori

dan. Kebijakan, Jakarta, PT Rajagrafindo Persada,.

Mankiw, N. Gregory, (2006). Pengantar EkonomiMakro.Ghalia Indonesia.Jakarta.

Nopirin. (1996). Ekonomi Moneter, Buku 2 Edisi 1. BPFE Yogyakarta.

Rachbini, D.J. (2000). Pengembangan Ekonomi Dan Sumber Daya Manusia.Grasindo,Jakarta.

Sandyawati, Wiene. (2011) Valuta Asing Jurus Ampuh Dalam Kebutuhan Dana JangkaPendek Investor. Yogyakarta: GrahaIlmu,.

Sugiyono. (2010). Metode Penelitian Pendidikan Pendekatan Kuantitatif, kualitatif, dan R\&D. Bandung: Alfabeta

Sukirno, Sadono. 2004. Pengantar Teori Makro Ekonomi.Jakarta: PT Raja Grafindo Persada.

Triyoso, Bambang. (2004). Analisis Kausalitas Antara Ekspor dan 
Pertumbuhan Ekonomi di Negara ASEAN. FE USU : Medan.

Undang-undang No. 23 Tahun 1999, Tentang Bank Indonesia,

Wibowo. 2012. Manajemen Kinerja (Edisi Ke 3). Jakarta : Rajawali Pers
Yulianti, Sri Handaru. 2007. Dasar-dasar Manajemen Keuangan Internasional. Edisi kedua. Offset :Yogyakarta. 